\title{
Validity of Poster on the Characteristics of Candida sp. in the Water of Campus Toilet
}

\author{
Aminuddin Prahatamaputra, Hidayati Rahimah \\ Biologi Education Program, Faculty of Teacher Training and Education \\ Universitas Lambung Mangkurat \\ Banjarmasin, Indonesia \\ aminuddinpatra@unlam.ac.id
}

\begin{abstract}
One of Microbiology fields studies about the characteristics of fungi and water microbiology, but in learning process any local resource is not used. Water contains many inorganic and organic substances as the place for microorganisms live. Candida sp. can be freely found in soil, animal's feces and in the air, but Candida sp. in the water of campus toilet has not been identified yet. Therefore, the water of campus toilet can be used as the closest learning resource for college students at Biology Education FKIP Unlam Banjarmasin in Microbiology subject. Learning Information can get more scientific when it shows by a poster. This research aimed to describe the validity of the poster on characteristics of Candida sp. in the water of campus toilet at FKIP 1 Unlam Banjarmasin. The method used in this research was Research and Development $(R \& D$, and the steps were research and collecting information, planning, developing preliminary form of product, preliminary field testing, and main product revision. The result showed "Candida sp. Characteristics in the Water of Campus Toilet at FKIP 1 Unlam Banjarmasin" poster had high validity and high reliability.
\end{abstract}

Keywords-Poster Validity, Species Characteristic, Candida Sp, Water Of Campus Toilet

\section{INTRODUCTION}

Learning media show rapid development from time to time, but there are still not many contextual learning media based on local resources, such as the environment, humans, plants, and animals. Learning media based on local resources can help college students to understand learning materials more easily. However, in Biology Education of FKIP Unlam not many learning media based on local resources are developed and found yet.

One of Microbiology fields studies about the characteristics of fungi and water microbiology, but any local resource is rarely used. For instance, we can use oil water containing many inorganic and organic substances which place for microorganisms live as the resource [1]. Therefore, our environment is so potential to be used as learning sources, such as in the water of campus toilet that we use in daily activity. Based on conditions that have been observed, the water of campus toilet at FKIP 1 Unlam Banjarmasin is not clean and there is some dirt in the water tub base. Such condition may contain microorganisms, so it can be used as the closest learning resource for college students of Biology Education of FKIP Unlam Banjarmasin in Microbiology subject.

In our environment Candida sp can easily be found in soil, animals' feces and in the air [2]. Usually infection occurs after using toilet water that contains Candida sp after defecation, contaminated from nails or urine. Therefore, Candida sp easily contaminates the water of campus toilets which are public facilities. Research about Candida sp in toilet water at different locations have been found, but Candida $\mathrm{sp}$ in the water of campus toilet has not been identified yet.

Valid Microbiology learning media about Candida sp characteristics have never been developed before. Water microbiology topic will be more understandable if the students are given the materials about Candida sp characteristics in the water of campus toilet at their own campus, FKIP 1 Unlam Banjarmasin. Learning Information can be more scientific when it is displayed using a poster, which contains about experiment steps until obtained the test results. The poster is more permanent and the content is easy to understand in short time by the reader.

This research aimed to describe the validity of the poster on characteristics of Candida $\mathrm{sp}$ in the water of campus toilet at FKIP 1 Unlam Banjarmasin.

\section{METHOD}

The method used in this research was Research and Development (R\&D) with descriptive model describing step by step to produce a poster. The steps are described in Fig. 1.

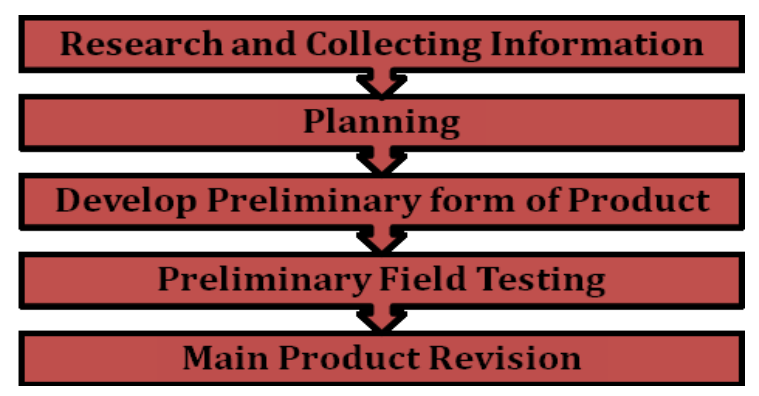

Fig. 1. Research and Development Steps 


\section{A. Research and Collecting Information}

The problem of this research was based on conditions that have been observed in the water of campus toilet at FKIP 1 Unlam Banjarmasin. The water might contain many inorganic and organic substances as the place for microorganisms live. Another problem in this research was that there are not many learning media based on local resources developed and found yet in Biology Education FKIP Unlam.

\section{B. Planning}

Some information was collected to make the development of the poster. The source of data of this research was the water of campus toilet at FKIP 1 Unlam Banjarmasin. Descriptive method implemented in this research was observing some toilets in FKIP 1 Unlam Banjarmasin, interviewing janitors and doing some laboratory tests on the samples. The population in this research wass all of the water in 24 toilets at FKIP 1 Unlam Banjarmasin. The samples in this research were $50 \%$ of the total sample, namely 12 toilets. The sampling technique in this research was area probability sample that used 6 toilets at the main building, 2 toilets at the back building, and 4 toilets at PMIPA building.

\section{Developing Preliminary Form of Product}

The product in this research and development ( $R \& D)$ was a poster about Candida sp's characteristics in the water of campus toilet at FKIP 1 Unlam Banjarmasin. The poster was designed for college students of Biology Education FKIP Unlam Banjarmasin in Microbiology subject. Poster is a development of abstract using illustrations (tables, figures, photos) [3]. The content of scientific poster as a learning medium includes: introduction, methods, results, discussion, conclusions and references.

\section{Preliminary Field Testing}

Design validation is the process to assess product design whether it is more effective than the old one or not. This research aimed to validate the poster by experts and by college students. Poster validation consisted of two steps. The first one was using validity instrument by expert who were thesis supervisors, and the second one was using readability instrument and held on 5 students of Biology Education S1 FKIP ULM Banjarmasin who have taken Microbiology subject. The small group trial was a trial of media by selecting 5-10 people who can represent the target population [4].

The results of expert validation were analyzed on the percentage and then validity can be measured using the following formula [5]:

$$
\mathrm{Pi}=\frac{x \mathrm{i}}{y \mathrm{i}} \times 100 \%
$$

The precentage will be known by the calculation using the formula. The product criteria are shown in Table I [5].

TABLE I. VALIDITY BY EXPERT CRITERIA

\begin{tabular}{|l|l|l|}
\hline \multicolumn{1}{|c|}{ Value } & \multicolumn{1}{|c|}{ Validity } & \multicolumn{1}{c|}{ Decision } \\
\hline $79.78-100 \%$ & High Validity & $\begin{array}{l}\text { New product can be used in } \\
\text { learning process. }\end{array}$ \\
\hline $59.52-79.77 \%$ & Valid & $\begin{array}{l}\text { Product can be used by } \\
\text { improving some aspects }\end{array}$ \\
\hline $39.26-59.51 \%$ & Low Validity & $\begin{array}{l}\text { Product can be used by } \\
\text { improving much aspects. }\end{array}$ \\
\hline $19.00-39.25 \%$ & Invalid & $\begin{array}{l}\text { Big revison and should be } \\
\text { consulted }\end{array}$ \\
\hline
\end{tabular}

The readability results of the poster measured by college student were analyzed the percentage, then validity can be measure using the following formula [6]:

$$
\text { Readibility }=\frac{\text { Tse }}{\text { Tsh }} \times 100 \%
$$

Tse $=$ Value of validator answer

Tsh $=$ Maximum value

The product criteria are displayed in Table II [6].

TABLE II. READABILITY BY COLLEGE STUDENT

\begin{tabular}{|l|l|l|}
\hline \multicolumn{1}{|c|}{ Value } & \multicolumn{1}{c|}{ Validity } & \multicolumn{1}{c|}{ Desicion } \\
\hline $81.00-100 \%$ & High Validity & Can be used without revision \\
\hline $61.00-80.00 \%$ & Valid & Can be used with revision \\
\hline $41.00-60.00 \%$ & Low Validity & Suggested not for used \\
\hline $21.00-40.00 \%$ & Invalid & Cannot be used \\
\hline $00.00-20.00 \%$ & Highly Invalid & Cannot be used \\
\hline
\end{tabular}

\section{E. Main Product Revision}

After the product design was validated by experts, the poster weakness can be identified. The weaknesses were listed in instrument validation. Then improvement was done based on the suggestions in instrument validation. Design improvements were implemented by the researchers to produce valid product until it reaches validity of $59.52 \%$ by expert and reaches $61.00 \%$ for readability by college students.

\section{RESUlT AND DISCUSSION}

\section{A. Result}

After the poster was designed, the validation by experts and validation by college students were conducted. The following is the result of the validity:

\footnotetext{
$\mathrm{Pi} \quad=$ Aspect precentage

$x \mathrm{i}=$ Value of validator answer

$y \mathrm{i} \quad=$ Maxium value
} 
TABLE III. VALIDITY RESULT BY EXPERTS AND READABILITY BY COLLEGE STUDENTS

\begin{tabular}{|c|c|c|c|}
\hline Value & Validity & Desicion & Criteria \\
\hline \multirow{2}{*}{$\begin{array}{l}\text { Validity by } \\
\text { Experts }\end{array}$} & Expert 1 & $79.13 \%$ & Valid \\
\hline & Expert 2 & $83.48 \%$ & $\begin{array}{l}\text { High } \\
\text { Validity }\end{array}$ \\
\hline \multirow{5}{*}{$\begin{array}{l}\text { Readability by } \\
\text { College } \\
\text { Students }\end{array}$} & $\begin{array}{l}\text { College Student } \\
1\end{array}$ & $77.50 \%$ & Valid \\
\hline & $\begin{array}{l}\text { College Student } \\
2\end{array}$ & $82.50 \%$ & $\begin{array}{l}\text { High } \\
\text { Validity }\end{array}$ \\
\hline & $\begin{array}{l}\text { College Student } \\
3\end{array}$ & $85.00 \%$ & $\begin{array}{l}\text { High } \\
\text { Validity }\end{array}$ \\
\hline & $\begin{array}{l}\text { College Student } \\
4\end{array}$ & $87.50 \%$ & $\begin{array}{l}\text { High } \\
\text { Validity }\end{array}$ \\
\hline & $\begin{array}{l}\text { College Student } \\
5\end{array}$ & $87.50 \%$ & $\begin{array}{l}\text { High } \\
\text { Validity }\end{array}$ \\
\hline
\end{tabular}

Poster validity based on validity by experts was measured using validity instrument that consisted of content aspect, language aspect, presentation aspect, visual aspect, and improvement suggestion. The validation was conducted by thesis supervisor 1 and thesis supervisor 2. The reulst can be seen in Table IV.

TABLE IV. POSTER VALIDITY BASED ON VALIDITY By EXPERTS

\begin{tabular}{|c|c|c|c|c|}
\hline No & Aspects & $\begin{array}{l}\text { Assesment } \\
\text { Component }\end{array}$ & $\begin{array}{c}\text { 1st } \\
\text { Validator }\end{array}$ & $\begin{array}{c}\text { 2nd } \\
\text { Validator }\end{array}$ \\
\hline \multirow{4}{*}{1.} & \multirow{4}{*}{ Content } & Fact accuration & 4 & 5 \\
\hline & & Theory accuration & 4 & 5 \\
\hline & & Method accuration & 2 & 4 \\
\hline & & $\begin{array}{l}\text { Suitability with } \\
\text { science depelovement }\end{array}$ & 5 & 5 \\
\hline \multirow{6}{*}{2.} & \multirow{6}{*}{ Language } & $\begin{array}{l}\text { Suitability with } \\
\text { science depelovement }\end{array}$ & 3 & 4 \\
\hline & & $\begin{array}{l}\text { Content language } \\
\text { understandability }\end{array}$ & 4 & 3 \\
\hline & & $\begin{array}{l}\text { Ability to encourage } \\
\text { student } \\
\text { thinking skill }\end{array}$ & 3 & 4 \\
\hline & & $\begin{array}{l}\text { Language structure } \\
\text { accuration }\end{array}$ & 3 & 2 \\
\hline & & $\begin{array}{l}\text { Use of term } \\
\text { consistency }\end{array}$ & 5 & 5 \\
\hline & & $\begin{array}{l}\text { Use of foreign term } \\
\text { accuration }\end{array}$ & 5 & 5 \\
\hline \multirow{5}{*}{3.} & \multirow{5}{*}{$\begin{array}{l}\text { Presen- } \\
\text { tation }\end{array}$} & $\begin{array}{l}\text { Presentation } \\
\text { arrangement }\end{array}$ & 5 & 5 \\
\hline & & $\begin{array}{l}\text { Illustration accuration } \\
\text { by presentation }\end{array}$ & 4 & 5 \\
\hline & & $\begin{array}{l}\text { Numbering and } \\
\text { naming of tables or } \\
\text { figures accuration }\end{array}$ & 2 & 2 \\
\hline & & $\begin{array}{l}\text { Variation in the } \\
\text { presentation }\end{array}$ & 3 & 4 \\
\hline & & $\begin{array}{l}\text { Completeness } \\
\text { presentation from } \\
\text { introduction, methods, } \\
\text { result, discussion, } \\
\text { conclusion } \\
\text { andreferences } \\
\end{array}$ & 4 & 4 \\
\hline \multirow[t]{2}{*}{ Visual } & & $\begin{array}{l}\text { The composition of } \\
\text { the layout elements } \\
\text { (title, author, } \\
\text { illustration,etc.) } \\
\text { balancedwith the } \\
\text { content layout }\end{array}$ & 5 & 5 \\
\hline & & Layout element size is & 4 & 4 \\
\hline
\end{tabular}

\begin{tabular}{lll}
\hline & $\begin{array}{l}\text { proportion with the } \\
\text { poster size }\end{array}$ & 5 \\
& $\begin{array}{l}\text { Poster color contrast } \\
\text { with the background } \\
\text { color }\end{array}$ & 2 \\
& $\begin{array}{l}\text { Font size proportional } \\
\text { compared to the poster } \\
\text { size }\end{array}$ & \\
& $\begin{array}{l}\text { Suitabilitythe poster } \\
\text { font and not use } \\
\text { ornamental/ decoration } \\
\text { font }\end{array}$ & 4 \\
& $\begin{array}{l}\text { Illustrations } \\
\text { describe the object } \\
\text { character and poster } \\
\text { content. }\end{array}$ & \\
\hline $\begin{array}{l}\text { The shape, color, size } \\
\text { based on proportions } \\
\text { of the object inreality }\end{array}$ & 4 \\
\hline $\begin{array}{l}\text { Overallillustration } \\
\text { well-suited, creative } \\
\text { and dynamic }\end{array}$ & 5 \\
\hline Votal score & & 5 \\
\hline
\end{tabular}

The poster validity measurement based on readability by college students was held with 5 students of Biology Education S1 FKIP ULM Banjarmasin who have taken the Microbiology subject. An instrument of readability measurement was used. Table $\mathrm{V}$ presents the results.

TABLE V. VALIDITy BASEd ON READABILITY By COLLEGE StUdENTS

\begin{tabular}{|c|c|c|c|c|c|c|}
\hline \multirow{2}{*}{ No. } & \multirow{2}{*}{ Aspect } & \multicolumn{5}{|c|}{ College Student } \\
\hline & & 1 & 2 & 3 & 4 & 5 \\
\hline 1. & $\begin{array}{l}\text { Poster design has been } \\
\text { interesting and describing } \\
\text { the contents }\end{array}$ & 4 & 4 & 4 & 3 & 3 \\
\hline 2. & $\begin{array}{l}\text { Images in the poster } \\
\text { interesting } \\
\text { appropriate to be } \\
\text { understanding }\end{array}$ & 3 & 3 & 3 & 3 & 4 \\
\hline 3. & $\begin{array}{l}\text { Images in the poster are } \\
\text { clear and not blurry }\end{array}$ & 3 & 3 & 4 & 4 & 4 \\
\hline 4. & $\begin{array}{l}\text { Texts in the poster using } \\
\text { clear font, font } \\
\text { combinations, colors, and } \\
\text { pictures are matching }\end{array}$ & 3 & 4 & 3 & 4 & 3 \\
\hline 5. & $\begin{array}{ll}\text { The sentences } & \text { are } \\
\text { understandable } & \end{array}$ & 3 & 3 & 3 & 3 & 3 \\
\hline 6. & $\begin{array}{l}\text { Images areclear and } \\
\text { understandable }\end{array}$ & 3 & 3 & 4 & 3 & 4 \\
\hline 7. & Terms are understandable & 3 & 3 & 3 & 4 & 3 \\
\hline 8. & $\begin{array}{l}\text { The material presented in } \\
\text { the poster has been } \\
\text { coherently }\end{array}$ & 3 & 4 & 4 & 4 & 4 \\
\hline 9. & $\begin{array}{l}\text { There is no sentence that } \\
\text { causes a double meaning } \\
\text { (ambiguous) in this } \\
\text { poster }\end{array}$ & 3 & 3 & 3 & 4 & 4 \\
\hline 10 & $\begin{array}{l}\text { Fungi and Water } \\
\text { Microbiology material } \\
\text { can be understood easily } \\
\text { using this poster }\end{array}$ & 3 & 3 & 3 & 3 & 3 \\
\hline Total & I score & 31 & 33 & 34 & 35 & 35 \\
\hline Valid & lity Percentage (\%) & $\begin{array}{l}77.5 \\
0\end{array}$ & $\begin{array}{l}82.5 \\
0\end{array}$ & $\begin{array}{l}85.0 \\
0\end{array}$ & $\begin{array}{l}87.5 \\
0\end{array}$ & $\begin{array}{l}87.5 \\
0\end{array}$ \\
\hline
\end{tabular}


Based on the validation, there were a lot of suggested improvements. The following is the result of design revisions that have been made referring to suggestion contained on aspects of assessment.

TABLE VI. SUGGESTION FOR IMPROVEMENT BY THE EXPERTS

\begin{tabular}{|c|c|c|c|}
\hline No. & Validator & $\begin{array}{l}\text { Suggestion for } \\
\text { Improvement }\end{array}$ & Revision \\
\hline 1. & Expert 1 & $\begin{array}{l}\text { Improve the concept } \\
\text { accuracy and the } \\
\text { research procedures } \\
\text { flowchart. } \\
\text { Improve sentence } \\
\text { structure for } \\
\text { encouraging student } \\
\text { critical thinking skill. } \\
\text { Figures numbering } \\
\text { and tables should be } \\
\text { sorted as well. }\end{array}$ & $\begin{array}{l}\text { The research } \\
\text { procedure } \\
\text { flowchart has been } \\
\text { revised based on } \\
\text { the suggestion. } \\
\text { The sentence } \\
\text { structure is } \\
\text { changed and the } \\
\text { numbering is } \\
\text { already sorted. }\end{array}$ \\
\hline 2. & Expert 2 & $\begin{array}{l}\text { Put the title above the } \\
\text { table, based on } \\
\text { scientific writing } \\
\text { rules. For the results } \\
\text { and discussion, please } \\
\text { improve it and adjust } \\
\text { the font size. }\end{array}$ & $\begin{array}{l}\text { The title table has } \\
\text { been moved to } \\
\text { top. Result and } \\
\text { discussion have } \\
\text { been improved } \\
\text { based on the } \\
\text { suggestion and the } \\
\text { font size has been } \\
\text { adjusted. }\end{array}$ \\
\hline 3. & $\begin{array}{l}\text { College } \\
\text { Student } 1\end{array}$ & $\begin{array}{l}\text { The image can be } \\
\text { presented more } \\
\text { clearly and some } \\
\text { materials are random. }\end{array}$ & $\begin{array}{l}\text { The image has } \\
\text { been clarified and } \\
\text { enlarged, the } \\
\text { material presented } \\
\text { is already sorted } \\
\text { correctly. }\end{array}$ \\
\hline 4. & $\begin{array}{l}\text { College } \\
\text { Student } 2\end{array}$ & $\begin{array}{l}\text { The design is nice, } \\
\text { but not to bother the } \\
\text { content. Images are } \\
\text { presented fairly } \\
\text { obvious, but it is } \\
\text { better when using a } \\
\text { DSLR camera. The } \\
\text { sentence in the poster } \\
\text { is understandable, but } \\
\text { it should improve. }\end{array}$ & $\begin{array}{l}\text { The design has } \\
\text { been corrected and } \\
\text { images have been } \\
\text { edited by contrast } \\
\text { and brightness. } \\
\text { The sentence has } \\
\text { been corrected. }\end{array}$ \\
\hline 5. & $\begin{array}{l}\text { College } \\
\text { Student } 3\end{array}$ & $\begin{array}{l}\text { Poster image should } \\
\text { be added more about } \\
\text { research and caption } \\
\text { in the table is placed } \\
\text { above. }\end{array}$ & $\begin{array}{l}\text { Image has been } \\
\text { added and caption } \\
\text { has been moved } \\
\text { above the table. }\end{array}$ \\
\hline 6. & $\begin{array}{l}\text { College } \\
\text { Student } 4\end{array}$ & $\begin{array}{l}\text { Poster design has } \\
\text { been interesting, but } \\
\text { could be made better. } \\
\text { There are still images } \\
\text { less clear. There are } \\
\text { some lines that are } \\
\text { still difficult to } \\
\text { understand. The } \\
\text { picture is enlarged } \\
\text { again in the process } \\
\text { of research activities. } \\
\text { Materials are } \\
\text { understandable, but } \\
\text { they are scattered and } \\
\text { not focused on the } \\
\text { discussion. }\end{array}$ & $\begin{array}{l}\text { Poster design has } \\
\text { been improved } \\
\text { and the image has } \\
\text { been enlarged for } \\
\text { more clear. } \\
\text { Sentence poster } \\
\text { has been } \\
\text { revamped and the } \\
\text { material } \\
\text { focussedon } \\
\text { thediscussion. }\end{array}$ \\
\hline
\end{tabular}

\begin{tabular}{|c|c|c|c|}
\hline 7. & $\begin{array}{l}\text { College } \\
\text { Student } 5\end{array}$ & $\begin{array}{l}\text { Poster colors and } \\
\text { writing should be } \\
\text { more varied. The } \\
\text { sentence } \\
\text { replaced with another } \\
\text { appropriate word. } \\
\text { There is a sentence } \\
\text { that unclear. The } \\
\text { material sorted } \\
\text { already coherently, } \\
\text { but need to be } \\
\text { completed. }\end{array}$ & $\begin{array}{l}\text { Colors designed } \\
\text { more varied } \\
\text { colors. The } \\
\text { sentence has been } \\
\text { replaced with } \\
\text { appropriate word. } \\
\text { The material has } \\
\text { been improved to } \\
\text { make it more } \\
\text { complete. }\end{array}$ \\
\hline
\end{tabular}

\section{B. Discussion}

The poster design that has been made was appropriate since it included the introduction, methods, results, discussion, conclusion and bibliography. This was in accordance with the opinion of [3] that the poster is an enrichment of abstract by using illustrations (tables, drawings, images).

Implemented steps in designing the poster was appropriate since there were clear verbal information, the listed elements poster complete, color and physical quality combined with a good poster, appropriate size and composition. The presentation of data in a poster was also good. This is due to several consultation meetings with the experts, some improvements based on suggestion, and the implemented steps already referred to the scientific literature of poster guidelines [3]. The poster was able to proceed to the next stage of design validation.

Validation by experts was held only once because the validity results have been reached. The results from the first validator showed the percentage value $79.13 \%$, while the second validator gave $83.48 \%$, so the validity of the poster was considered as high validity by experts. As the poster has reached high validity criteria, it can be followed by design revisions and improvements without second validation.

Based on the validation scores in Table IV, aspect of language regarding language structure accuracy was considered low validity as there were still some bad structures that need to be improved. Aspect of language structure accuracy is the phrase used to represent the content of the message should be corrected into Indonesian language structure [7].

Furthermore, the presentation aspect regarding to numbering and naming of tables or figures was at low validity. It is caused by wrong position of table title, so it must be revised by moving title to the above the table. The aspects of numbering tables, images, and attachment sequence and the title should match the specification in the text.[7]

Presentation aspect is varied and not boring to the reader. There are various explanations such as images, tables, and graphs to make the poster easy to understand. The visual aspects such as size comparison between the layout, size elements (typography, illustrations and other supporting elements) must be proportionate. In addition, the product must be able to dynamically visualize things that can encourage readers' comprehension and understanding of the presented material. 
The validation is to determine the validity of learning material based on the contents, language, presentation and visual aspects [8]. Valid learning materials have been able to be used in the learning process. Development of learning materials supports the good and more focused learning process.

Readability test involving college students was held only once as the results has reached high validity. The poster validity results obtained from the students were $77.50 \%$, $82.50 \%, 85.00 \%, 87.50 \%$ and $87.50 \%$. Therefore, the product can be used without revision. Nevertheless, college students still gave some improvement inputs on some aspects that still achieved score of 3 for the betterment of the poster. The poster can be followed by the step of design revisions and it did not need the second validation by the college students.

Based on the validation scores in Table $\mathrm{V}$, the fifth and tenth aspect only reached score of 3 . The fifth aspect was about sentence comprehension in the poster, and the scores were caused by some incomprehensible words which needed to be improve. Aspects of understandable sentence is a sentence that used to represent the content of the message and follow the correct Indonesian language structure [7].

The tenth aspect was about understandability Fungi and Water Microbiology material by using this poster did not have maximal score since the poster has limitations in terms of size and content. Scientific poster is a medium that is easy to understand in terms of the content in a short time by the reader, so that it does not need to be too much but can be maximized with the visual communication. The enrichment of the scientific poster abstract was done to strengthen it uses illustrations (tables, drawings, images) [3]. The poster was revised at the next step of research and development that was design revision.

Design revision can be implemented based on the suggestions by validators in design validation step. After the product design was validated through discussions with experts, the weaknesses was known. The weakness was further tried to be reduced by improving the design [9].

The first expert validator suggested the improvement of the concept accuracy, flowchart of research procedures, language sentence structure, as well as the numbering of figures and tables. Revisions were implemented to improve research procedure flowchart, the language sentence structure was corrected and the numbering was already sorted. Revision of the design has been done to make the poster better, so it left second validation as the poster was valid.

Second expert validator suggested that the title was placed above the table in accordance with the rules of writing scientific papers. Parts of results and discussion were improved again and the font size was adjust. Thus, the poster was revised based on the feedback. A revised draft of the poster was implemented based on expert validation so that results were better and in accordance with the theory [6].
The five college students as the validators also gave suggestion about the image and the material presented. The images on the poster were requested to be enlarged and clear. The revised design was larger image size than the previous version and the poster was also edited for image contrast and brightness. The material presented in poster was revised by adjusting the sentence structure and the words. Poster material is added with more complete information in order to improve the understanding for college students and other readers. This revision related to the effort to ensure understanding of readers is important since the function of instructional media is to clarify or enrich the information provided verbally and attract the attention of students to learn. Thus, design revisions according to the college students aimed to make the poster information easy to understand [10].

\section{ACKNOWLEDGMENT}

Thanks to everybody who encourage us to finish this paper. This paper is far from perfect, but it is expected that it will be useful not only for the researcher, but also for the readers. For this reason, constructive thoughtfull suggestion and critics are welcomed.

\section{REFERENCES}

[1] Dwidjoseputro, Dasar-Dasar Mikrobiologi, Surabaya: Djambatan, 2010.

[2] S. Gandahusada, W. Pribadi, and H. D. Ilahude, Parastiologi Kedokteran, $3^{\text {rd }}$ Ed. Jakarta: Fakultas Kedokteran Universitas Indonesia, 2006.

[3] A. W. Gunawan, D. Prijono, D. A. Astuti, D. Suhardjito, and E. S. Wahyuni, Pedoman Penulisan Karya Ilmiah, Bogor, 2012.

[4] Istiana, "Pengembangan Media Pembelajaran Menggambar Busana Menggunakan Adobe Flash CS4 untuk Siswa Kelas X Busana SMK Negeri v3 Klaten," Thesis, Yogyakarta: Fakultas Teknik UNY, 2012.

[5] D. Pratiwi, Suratno, and Pujiastuti, "Pengembangan bahan ajar biologi berbasis pendekatan SAVI (Somatic, Auditory, Visual, Intellectual) pada pokok bahasan sistem pernapasan kelas XI SMA dalam meningkatkan motivasi dan hasil belajar siswa," Jurnal Edukasi Unej, I (2), 2014, pp.59 .

[6] S. Akbar, Instrumen Perangkat Pembelajaran, Bandung:Remaja Rosdakarya, 2013.

[7] BSNP, Instrumen Penilaian Buku Teks Pelajaran Tahun 2014, Jakarta: BSNP, 2014.

[8] A. Hidayati, and S. Handayani. (2014). "Validitas pengembangan handout berbasis model conceptual change teaching pada perkuliahan Fisika Dasar di STKIP PGRI Sumatera Barat”. Jurnal Riset Fisika Edukasi dan Sains. 1 (1), 2014, pp.41-46.

[9] Sugiyono, Metode Penelitian Kuantitatif Kualitatif dan $R \& D$, Bandung: Alfabeta, 2011

[10] S. Welya, S., Daningsih, and Titin. "Kelayakan poster kandungan gizi jeruk pada sub materi Zat Makanan," Jurnal Pendidikan dan Pengembangan, 5 (11), 2016, pp.1. 